\title{
1. International investment law and the environment: introduction
}

Kate Miles

Public international law forms an umbrella framework under which its various substantive areas of law sit. The fragmentation this represents is a well-known phenomenon in international law and its implications are manifold. ${ }^{1} \mathrm{~A}$ key aspect of this fragmentation and increasing specialisation is the potential for competing norms to encounter each other within the international legal space. There seem to be several mechanisms for resolution of this available in theory, and not a great deal of consistency in practice. One area of contestation in particular has attracted controversy, largely due to the public interest issues implicated, the asymmetries in dispute settlement approaches and the prioritising of one set of norms over another - environmental law, policy and protection objectives and international investment law.

The environment/investment nexus became a high-profile international issue through a number of coinciding, parallel channels. On one level, the damaging effects of the activities of multinational corporations on the environment and the health and well-being of local communities formed the backdrop against which international legal issues would be played out. Catastrophic examples of this mode of encounter included the Bhopal disaster, the 'dieback' experienced downstream from the BHP copper and gold mine at Ok Tedi and Chevron/Texaco's leaching of crude oil into the Amazonian ecosystem. At the same time as such micro-level incidents were occurring, global environmental issues that involved multinational corporate operations, such as climate change and the need for the widespread adoption of policies aimed at achieving sustainable development, were appearing in international instruments. The environment/investment nexus also became particularly visible in the late 1990s in the context of investor-state arbitration, when environment-related investment disputes began to be filed with international tribunals, which then triggered extensive protests regarding the negotiation of a Multilateral Agreement on Investment under the auspices of the Organisation for Economic Co-operation and Development (OECD). From that point onwards, the interaction between the treatment of environmental issues and norms and the rules contained within international investment agreements remained controversial.

The multiplicity of forms taken by that interaction is the core theme of this book. What emerges out of these chapters is a sense that we are still very much in the process of articulating the exact nature of the relationship between environmental protection and foreign investment protection and that there persists a need to ascertain where on the scale

1 See, for example, the International Law Commission, Fragmentation of International Law: Difficulties Arising from the Diversification and Expansion of International Law, Report of the Study Group of the International Law Commission, finalised by M. Koskenniemi, UN Doc. A/CN.4/L.682 (13 April 2006). 
of contestation a 'balanced' approach should lie. At its core, it remains a debate about the way in which the 'public' and the 'private' should be reconciled within international law, but it is also clear that the discourse in the environment/investment field has shifted to a deeper, more indepth and sophisticated level. It has moved beyond identifying the issues to a general recognition that there are problems and to an interrogation of the detail, engaging with the complexities, nuance and variance within subareas of environmental issues and exploring options for resolution of conflicting objectives and outcomes. The discourse now also acknowledges the difference in perspectives among stakeholders and commentators, and that there is room for divergence in interpretation and proposed solutions. This book is an illustration of the capacity to encompass that varied landscape.

In fact, it is fascinating to see the possible diversity of viewpoints on well-known cases and principles. Where the same disputes are discussed in several chapters, very different perspectives are brought to the analysis by the different authors, each taking a distinct angle for their enquiry or situating the dispute within the context of the subject of their individual chapters. In this sense, there are, at times, substantive overlaps, but there is also variance in interpretations, viewpoints and stances on those issues. This is precisely a reflection of the more sophisticated place at which the discourse has now arrived, and those chapters represent a cross-section of approaches to key cases that involve the interaction of environmental protection and investment law.

The structure of the volume is designed to excavate the environment/investment nexus in such a way as to reflect the multiple angles from which we can understand its nature. For this reason, each of the chapters can stand alone as an indepth analysis of a specific issue. But they also all interact and create a cohesive whole, providing a comprehensive account of the interaction between the environment and investment law. Part I of the volume takes as its starting point an environmental platform, analysing the relationship from the angle of specific environmental issues. It opens with a chapter by Professor Jorge Viñuales examining the current 'state of play' in the interaction between environmental protection objectives and international investment law. In particular, he examines what he calls 'the trends that have moved from forecast to reality', and in that process also engages in further forecasting. To this end, he discusses environmental clauses in international investment agreements, the surge in investment claims with environmental components and more progressive modes of interpretation, all of which contribute to a normalising of environmental reasoning in investment jurisprudence. A key theme of Professor Viñuales' chapter is that mainstream actors in international investment law and arbitration are increasingly aware of the significance of environmental matters within the investment context and that this is indicative of a change in 'mindset' within the field. Furthermore, with a view to the future, Professor Viñuales considers that the space for consideration of environmental protection within international economic law is a continuously expanding and evolving one.

Having set the stage with an assessment of general trends in the field in Chapter 2, Part I continues with a detailed examination of individual environmental issues. Professor Andrea $\mathrm{K}$. Bjorklund considers that most fundamental of relationships in the investment and environment nexus - sustainable development and international investment law. She explores the initiatives states are taking to reconcile the protection of investment with principles of sustainable development and the protection of human, animal and plant life and health. In the course of her discussion, Professor Bjorklund articulates the nature of sustainable 
development as a concept and principle and the incorporation of non-economic objectives into investment treaties. She analyses the tensions and potential synergies between international investment law and sustainable development through the lens of an iconic case, Bilcon $v$ Canada. $^{2}$ Mirroring the conclusions of Professor Viñuales, Professor Bjorklund argues that treaty drafters, investors and tribunals in investor-state disputes are unquestionably more cognisant of the need to consider the principle of sustainable development, but she also points to a series of challenges that remain. In particular, she highlights the inherent intrusion into state sovereignty represented by investment treaties and the decisions of investment tribunals, and the difficulties of differentiating between permissible and undesirable constraint of state action; she explores the complexities of competing interests and different 'sustainabilities' of separate stakeholders requiring protection; and she suggests the need for more proactive engagement to promote closer harmonising of objectives.

The remaining chapters of Part I are linked through the shared approach that is taken by each author, namely a close examination of the interrelationship of a key sub-area of environmental law and policy with international investment law - water, climate change, biodiversity and biotechnology, and environment and human rights. A recurring theme throughout these chapters is the exploration of the current space within investment treaty regimes for non-investment considerations, and this is very much reflected in Chapter 4 by Professor Ursula Kriebaum, examining water. She emphasises the multifaceted nature of water as a vital source of life, a commodity and a scarce resource; as such, she paints a picture of an entity that not only has environmental implications and holds commercial value, but also incites an emotional response from humans. Professor Kriebaum delineates the types of investment cases that have an impact on water, being those that have arisen out of privatisation in the water sector and those that arise in a variety of industries that have a potential to degrade water quality or have a negative impact on the marine environment. In her chapter, she traverses the international legal framework for water, explores requirements for access to clean water and assesses the way in which investment tribunals have approached the complex, layered nature of water-related cases.

As with water, climate change is also a particularly controversial area in which the investment and environment fields meet. Again, the theme of reconciling the needs of both private investment and public interest is very much to the fore in Chapter 5 , by Professor Freya Baetens. She examines the way in which climate change-related investment disputes are addressed within the generic investor-state arbitral framework rather than any regime-specific climate dispute settlement system. She considers investment projects implemented under the Kyoto Protocol, the role envisaged for private investment under the Paris Agreement and the potential conflicts between investment protection standards and domestic measures implementing climate change mitigation objectives. Professor Baetens then explores climate-related investment disputes that have already arisen both in a contract and a treaty context. In terms of a way forward and a more harmonised approach, she essentially argues for shifts in future treaty drafting and cautious climate-friendly reinterpretations of existing principles and investment protection standards by arbitral tribunals.

2 William Ralph Clayton et al and Bilcon of Delaware, Inc. $v$ Government of Canada, UNCITRAL, Award on Jurisdiction and Liability (17 March 2015). 


\section{Research handbook on environment and investment law}

A subset of the environment/investment relationship that is perhaps less frequently examined is that of the implications for biodiversity and biotechnology. Associate Professor Anastasia Telesetsky fills that gap in Chapter 6, exploring the multiple dimensions to this mode of interaction. She first considers how investment law might shape future investments in emerging biodiversity-reliant industries, before setting out the potential investment implications of state strategies to conserve biodiversity, such as the creation of protected areas. She analyses the concluding of 'access and benefit sharing agreements' as a formal investment mechanism in sustainable biodiversity. She also examines private investment in biodiversity protection through the provision of ecosystem services and initiatives such as habitat banking, biodiversity offsets and 'biobanking'. Again, much like each of the authors in this volume, Professor Telesetsky moves beyond identification of the contentious issues to provide an indepth analysis of their implications and the potential avenues for reconciliation of competing interests, in this case through better biodiversity management and more accountable international investment.

The final chapter in this first part of the book examines the complex three-way intersection of the environment and investment with human rights. As a very concrete illustration of this juncture, Elliot Luke begins his analysis with the Indonesian forest fires of 2015 and the speculation at the time that the environmental destruction could give rise to investment arbitration as well as constituting a violation of Indonesia's international human rights obligations. From this standpoint, Luke reviews the development of the separate substantive regimes and then presents a sketch of the way in which investment law accounts for the links between the environment and human rights. In so doing, he considers various proposals to integrate different fields within international law and applies those approaches to the environment/investment and human rights interconnection.

Part II of this book focuses on specific areas of engagement encompassed within a framework of 'Disputes, Procedure and Practice in the Field'. In contrast to Part I, this section takes as its starting platform investment law perspectives. This includes a comprehensive exposition on investment treatment standards in environment-related investor-state disputes, the role played by procedure in the environment/investment nexus, the increasing significance of science in environment-related investment disputes, the controversies surrounding notions of 'green multilateralism' and the interplay of investor-state arbitration and the green economy. Each chapter addresses contentious issues that have arisen in the course of experiencing the environment and investment law relationship in practice and in treaty-drafting. Opening this section, Professor Chester Brown and Domenico Cucinotta provide a full account of what the core investment treatment standards entail. In this chapter we find a detailed analysis of the guarantees of protection against expropriation, the obligation to accord fair and equitable treatment to investors and the requirements to provide most-favoured-nation treatment and national treatment. Recognising the potential for conflicting demands on states between fulfilling these obligations and those under international environmental agreements, the authors look to rules of public international law, such as those contained in the Vienna Convention on the Law of Treaties, ${ }^{3}$ as a possible source through which to reconcile those

3 Vienna Convention on the Law of Treaties, opened for signature 23 May 1969, 1155 UNTS 311 (entered into force 27 January 1980). 
competing obligations. The chapter then appraises a series of key investment disputes that have raised environmental considerations and gives particular attention to the way in which arbitral tribunals have sought to rationalise their decision-making. In this way, the discussion embodies Part II's emphasis on the practice of dispute resolution in the field and the experience of the environment/investment interlinking as an outcome of arbitral proceedings. A further key component of such an analysis is, of course, the procedural framework that shapes the context for the hearing of those disputes, which is the angle adopted in the next chapter in Part II.

In recent years, the importance of procedure in investor-state arbitration has become more widely appreciated - and it is no different for the environment/investment nexus. With this in mind, in Chapter 9 Judith Levine and Nicola Peart articulate the significance of procedural developments for environment-related investment disputes, identifying particular procedural issues that relate to two characteristics common in environmentrelated cases, being the public interest and technical evidence. In reviewing individual claims, the authors focus on aspects of transparency and confidentiality, the involvement of non-parties, the appointment of technical experts, the conduct of site visits and the management of costs. They also reflect upon evolving procedural innovations that may be particularly relevant for environment-related investment disputes, including the development of subject-specific, bespoke arbitral rules and specialist arbitrator panels; alternative methods of dispute resolution; and the monitoring of post-award compliance. The core message from this chapter is the adaptability of arbitration as a dispute settlement tool and its suitability for the resolution of environmental disputes. The discussion in this chapter on the significance of procedure, and in particular on the use of technical experts for environment-related investor-state arbitration, leads into detailed examination of one aspect of this area in Chapter 10. In this regard, Professor Jacqueline Peel looks specifically at the use of science in such cases.

Given the specialist expert knowledge required to understand complex environmental systems and impacts, scientific data plays an inherent and central role in disputes with an environmental component. Professor Peel explores the way in which international courts and tribunals have had to make sense of such technical information and to engage with questions that go to the heart of the relationship between law and science. In the practice of investor-state arbitration, tribunals determining disputes with an environmental element have also had to confront similar questions around the appropriate use of science. Professor Peel examines the different approaches to the role of science that can be discerned from these cases and the methods adopted by tribunals for evaluating the scientific evidence and risk assessments used by states to justify their environmental regulatory measures. In so doing, she also brings into the discussion the role of the precautionary principle in managing scientific uncertainty and proof of harm, and the part experts play in advising arbitrators and informing arbitral decisions. In analysing well-known cases - Metalclad v Mexico, ${ }^{4}$ Methanex v United States, ${ }^{5}$ Bilcon v Canada ${ }^{6}-$ through

\footnotetext{
4 Metalclad Corporation v Mexico (ICSID Case No ARB(AF)/97/1, Award of 30 August 2000).

5 Methanex Corporation v United States (Final Award on Jurisdiction and Merits of 3 August 2005).
}

${ }^{6}$ William Ralph Clayton et al and Bilcon of Delaware, Inc. $v$ Government of Canada, UNCITRAL, Award on Jurisdiction and Liability (17 March 2015). 


\section{Research handbook on environment and investment law}

the lens of their use of science, Professor Peel not only draws out a new understanding of these specific cases, but also adds another layer to environment-related investor-state arbitration more broadly.

The negotiation of high-profile multilateral free trade and investment agreements has been particularly contentious. One of the most recent is the Comprehensive and Progressive Agreement for Trans-Pacific Partnership (TPP11) and this is the prism through which Dr Sam Luttrell analyses the relationship between environmental protection and investment law in Chapter 11. In particular, he argues that the two objectives of protecting the environment and promoting economic development are being balanced in the new generation of multilateral investment treaties as exemplified by TPP11. As a practitioner in the field of investor-state arbitration, Dr Luttrell provides a valuable perspective for those seeking to understand the implications of the environment/investment nexus for advising clients, whether states or investors. With this in mind, he sets out treaty frameworks the practitioner will encounter, including a sketch of the history of bilateral investment treaties and multilateralism. Dr Luttrell then focuses on the substantive treaty protections of expropriation and fair and equitable treatment and defences available under customary international law, following which he moves to a close analysis of the TPP11, describing it as 'the most recent expression of green multilateralism'. He explains how the TPP11 states have drafted provisions so as to preserve their rights to regulate in key areas, including protection of the natural environment, and then considers in detail the investment chapter of the treaty. He also speculates on the increasing centralisation of investor-state dispute settlement and argues that the prospect of standing international investment courts can only be a positive development for the consideration of environmental protection in investment disputes.

The final chapter of Part II assesses the workings of the investor-state dispute settlement system from the angle of facilitating the transition to a green economy. Assistant Professor Kyla Tienhaara evaluates claims that investor-state arbitration can make a positive contribution to environmental protection through its capacity to incentivise the injection of foreign capital into renewable energy projects, because it provides security for investors against regulatory change and therefore assists with building a low-carbon, 'green' economy. Assistant Professor Tienhaara focuses particularly on assertions that have been made in light of disputes filed against Canada regarding wind energy projects and Spain's solar cases. She explores the different understandings of what a green economy means and argues that, on any conceptualisation, there is little evidence to suggest that the investor-state dispute settlement system has a positive role to play in supporting the emergence of a green economy. In fact, she argues, the need for wind and solar investments specifically to receive protection from investment treaties is now limited and declining.

Having examined the issues from more generalised environmental and investment viewpoints in Part I and II, the book takes a different path in Part III. Appreciating that geographic considerations can result in very different perspectives on the environment/ investment nexus, Part III explores regional approaches to the relationship between environmental protection and international investment law. This section begins with a discussion by Dr Romesh Weeramantry and Montse Ferrer on the shift in emphasis of India's more recent investment treaties and their increasingly prevalent exceptions for environmental regulation. The authors provide a detailed account of India's 2015 Model 
BIT and examine the impact of a particularly significant award made against India, White Industries $v$ India, ${ }^{7}$ which was a contributing factor in subsequent changes to treaty drafting designed to ensure greater regulatory space for India. They also explore India's current environmental concerns, energy needs and economic development objectives and how these tensions converge in the investment context. In particular, they draw attention to the future 'flash point', as these competing interests increasingly meet, that is likely to occur around the provisions in India's latest investment treaties that expressly carve out discretion for the government to regulate the environment.

The convergence of energy, environment and local community needs is also a theme in Chapter 14, as Dr Sotonye Frank examines an aspect of the environment/investment relationship that is of particular concern for many states in Africa - the use of stabilisation clauses in long-term investment contracts in the energy sector. Dr Frank articulates the heightened political risk and vulnerability of investments in the oil, gas and electricity industries because they tend to involve projects of a particularly capital intensive and long-term nature. He argues that it is therefore common for investors in this sector to seek out stabilisation clauses to ensure that the regulations governing their investment will not change to their detriment, and that this is particularly so for projects in Africa, where the perception of risk is higher than for other regions. He points to the potential implications of such clauses for host state regulatory space and, in particular, for the sustainable development trajectories of African states. Dr Frank analyses the types and scope of stabilisation clauses used in Africa's energy sector, concluding that there is little evidence that a willingness to provide stabilisation clauses correlates to an increase in foreign investment inflows in this region and that although a wide variety of approaches are being adopted in stabilisation clauses, there is also currently a distinct move away from the more expansive forms to narrower models that exclude changes in environmental and health regulation. In other words, African states are increasingly offering clauses that allow for more flexibility so as to create greater space for host state regulatory needs.

The meeting of interests in energy, development, environment and investment is a potentially contentious mix in yet another setting - in Chapter 15, that of China. In her chapter, Associate Professor Danni Liang conveys a sense of the complex modes of interaction that are evident in the environment/investment relationship from China's perspective. Encompassing both the positive and negative effects of foreign investment in China, Associate Professor Liang's chapter discusses the rapid economic growth experienced in China and its accompanying environmental degradation, particularly the concerns expressed at the levels of air and water pollution in the country. Against this backdrop, she considers the different phases in the drafting of China's international investment treaties and tracks the appearance of environmental concerns in such agreements. She identifies the increasing insertion of text relating to environmental protection that goes beyond preambular language and contains substantive obligations. Such provisions include requirements to maintain environmental standards, the preservation of environmental regulatory space, environment-related expropriation clauses and carve-outs containing general exceptions or more specific exceptions for public welfare regulation. Associate

White Industries Australia Limited v Republic of India, UNCITRAL, Award of 30 Nov. 2011, Final Award. 
Professor Liang argues that this new generation of China's investment treaties indicates a steadily increasing appreciation of the need for express integration of environmental concerns into investment treaties. She then considers the way in which, through a focus on sustainable development, China's future treaty-drafting decisions could reconcile still further the needs of both investment and environmental protection in China's investment agreements.

In a similar vein to Associate Professor Liang's assessment of China's approach to its investment treaties, in Chapter 16 Dr Rumiana Yotova discusses the extent to which new European Union (EU) investment agreements balance economic protection and environmental considerations. She explains that the content of the new generation of EU investment treaties needs to be seen in the context of states responding to the early awards of investor-state tribunals that did not take adequate account of noninvestment interests and that this is an attempt to remedy that failure through treaty drafting. In considering a series of reform agendas, Dr Yotova first examines the Founding Treaties of the EU for their approach to balancing the competing interests of environmental protection and investment. She also explains how the EU's internal institutional structures impact on its approach to the environment/investment nexus and the formulation of the new EU International Investment Policy, focusing in particular on the acts of the European Commission, the European Parliament and the Council of the EU. A detailed analysis of key EU investment treaties follows, pointing to a general trend in the strengthening of environmental protection references within such agreements, but suggesting that they are perhaps not as strong or progressive as might have been expected.

Latin American states have been respondents in a substantial number of investor-state arbitrations; this is also a region particularly rich in biodiversity. Accordingly, the final chapter in Part III considers the environment/investment linking from a Latin American perspective. Dr Gabriel Bottini and Elisa Méndez Bräutigam examine the defences relating to environmental protection that have been advanced by Latin American states in investment arbitration and unpick the legal tension between such arguments and investment protection obligations. The authors provide a thorough, state-by-state description of the environment-related investment claims that have been faced by states in Latin America. They then focus on questions around the extent to which non-investment national or international law may feature in determining whether an investment treaty obligation has been breached. In particular, they analyse general principles of international law, including rules relating to ascertaining the applicable law in international disputes, and argue that it is consistent with those general principles for tribunals to consider environmental obligations that are binding on the host state when deciding the merits of investment treaty claims.

Part IV of the volume takes a more atypical look at the environment/investment law convergence and explores issues that have in some respects perhaps received less attention in the mainstream literature to date. In this section, the authors examine not solely the relationship between environmental issues and investment protection, but that relationship as it pertains to other important, but less traversed, considerations. Its framing is that of 'identity and perspective; critique and conceptualisation' so as to encapsulate the varied, yet also fundamentally shared, approaches taken by the authors in this section. Opening the enquiry, in Chapter 18 Professor Rachel J. Anderson investigates specifically 
the relationship between environment, foreign investment and gender. She identifies the ways in which women and girls are both affected by and influence foreign investment and the environment and argues that this mode of interaction is currently underrepresented and undervalued in international legal research. Her chapter seeks to contribute to a remedying of that state of affairs. She draws attention to the problem of genderblindness in research, where gender is not considered to be an important factor in legal and policy decisions and outcomes. Professor Anderson also points to the inaccuracy of the widely held assumption that men and women experience the same impacts from foreign investment and environmental considerations, showing that gender in fact plays numerous and varied roles in regulation, policies and outcomes in both environmental and foreign investment law and policy.

In Chapter 19, Professor Valentina Vadi then takes the discussion into a consideration of the treatment of natural resources and indigenous cultural heritage in international investment law and arbitration. She examines the United Nations Declaration on the Rights of Indigenous Peoples, ${ }^{8}$ and the entwining of indigenous cultural identity, human rights and environmental identity. Professor Vadi sets out the ways in which indigenous cultural identity, particularly the dimensions relating to relationships with land and natural resources, have been engaged in investor-state arbitration and examines the approaches adopted by tribunals in key cases. She argues that cultures collide in the encounter of international investment law and indigenous cultural heritage and that that collision renders it all the more important to strengthen current regimes protecting indigenous heritage, including ensuring the participation of indigenous peoples in the decisions that affect them and their heritage.

The themes of the critique of international investment law and its relationship with the environment taken up in Professor Vadi's chapter continue into the analysis provided in Chapter 20, but here they are considered specifically from a development perspective. Associate Professor Ibironke T. Odumosu-Ayanu examines the environment/investment nexus as an issue interlinking local communities, environmental considerations and development objectives, and analyses these connections through a particularly significant case study - that of oil and gas investment in Africa. Acknowledging the contested nature of the concept of 'development', Associate Professor Odumosu-Ayanu focuses on the perspective of the local community, as the stakeholder most impacted by such projects and, at the same time, the group most marginalised in decision-making. She illustrates her arguments through a dissection of the Chad-Cameroon Petroleum Development and Pipeline Project, which promised 'development' and 'poverty alleviation' as well as environmental integrity. Her analysis points to the adoption of a hierarchical approach to local community engagement in projects of this kind that defeats the objectives of development. Exploring the implementation of modes of resistance and mechanisms for local community engagement, Associate Professor Odumosu-Ayanu makes the point that investor-state awards demonstrate 'an unease with the place of local communities in the foreign investment and environmental protection conversation'. She highlights how crucial it is to incorporate the voices of local communities into not only the design of

8 United Nations Declaration on the Rights of Indigenous Peoples, G.A. Res. 61/295, UN Doc. A/RES/61/295 (13 September 2007). 
largescale oil and gas projects that inherently implicate environmental and development considerations, but also the international investment law that governs such projects.

Chapter 21 offers yet another conceptualisation of the environment/investment fusion, in this instance engaging with notions of socially and environmentally responsible investment, and examines the shaping of the relationship between environmental and economic performance by the financial sector. Professor Benjamin J. Richardson first sets out the environmental impacts of financial markets and institutions themselves and argues for a more extensive role for finance in the promotion of sustainable development. He delineates the concept of 'socially and environmentally responsible investment', or 'SRI', and identifies current barriers to the wider embracing of the SRI market. Professor Richardson then explores areas to enhance the relevance of SRI and suggests ways in which those barriers can be overcome. Ultimately, he discusses the positive message on SRI that needs to be promoted beyond solely better financial returns, particularly that it contributes to a 'more just society, a better economy and a healthier environment'.

This book draws out the complex and multilayered dimensions of the relationship between environmental protection, foreign investment and international law. Seeking to provide a detailed account of those dimensions, the individual chapters move beyond generalisations and merely identifying modes of interaction between these fields. In fact, a full volume dedicated to the subject including multiple authors allows not only for indepth investigations, but also for the multiplicity of perspectives that exist in this area. In addressing a specific issue, position or standpoint, each chapter examines the precise concerns relevant for that manifestation of the environment/investment connection, together with their implications, possible pathways for reform and likely future directions. And, as a whole, these chapters knit together so as to present a comprehensive exploration of the relationship between environmental protection and international investment law. It is clear from this enquiry that the character of that relationship is still being drawn and its articulation is an involved and ongoing process. As treaty-drafters, policy-makers, arbitrators, states, investors and stakeholders continue to contend with the full spectrum of approaches to the mixing of public and private within international law, it is also clear that the diversity of views will enrich that discourse, deepen our understanding of the issues and generate ever more sophisticated responses - ultimately, that interaction is not relevant solely for the environment and investment fields, but also speaks to the engagement of investment law with other non-investment areas, as well as for the issue of competing interests and conflicting norms within international law more generally. It is hoped that the chapters in this volume will contribute in a meaningful way to those conversations. 